\title{
A PARASITIC ASSOCIATION OF ODONATA (INSECTA) WITH ARRENURUS DUGÉs, 1834 (ARACHNIDA: HYDRACHNIDA: ARRENURIDAE) WATER MITES
}

\author{
Raymond J. Andrew ${ }^{1}$, Payal R. Verma ${ }^{2}$ \& Nilesh R. Thaokar ${ }^{3}$ \\ 1,2,3 Post Graduate Department of Zoology, Hislop College, Nagpur, Maharashtra 440001, India \\ ${ }^{1}$ rajuandrew@yahoo.com (corresponding author), ${ }^{2}$ payalrverma@gmail.com, ${ }^{3}$ nilesh.thavkar@gmail.com
}

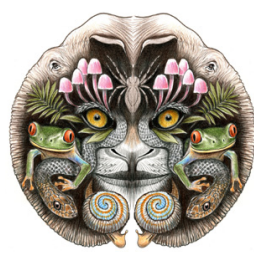

ISSN 0974-7907 (Online) ISSN 0974-7893 (Print)

OPEN ACCESS
Abstract: The parasitic association between water mites (Arrenurus spp.) and Odonata is virtually ubiquitous wherever habitats suitable for both taxa exist. Yet, very little is known about this association within and among the odonate species of India. Here, we present a report on this parasitic relationship in the population of odonates of Wena Dam of Central India observed during the years 2011 and 2012. Of the 376 odonates collected for observation, 35(9.3\%) individuals belonging to seven species (Acisoma panorpoides, Brachydiplax sobrina, Ceriagrion coromandelianum, Crocothemis servilia, Diplacodes trivialis, Neurothemis tullia tullia, Trithemis pallidinervis) were found to be parasitized by the Arrenurus spp. mites. The mites were found attached to the undersurface of the thorax and abdomen. In all the cases, the thorax was found infested while only in seven individuals the abdomen as well as the thorax was found infested with mites. A maximum number of mites on an individual dragonfly was in C. servilia (293) followed by T. pallidinervis (134) while the highest parasitic load per individual host species was found in T. pallidinervis (70.25\%) followed by C. servilia (32.6\%). The average parasitic load per individual female and male was 39.77 and 8.9 , respectively.

Keywords: Arrenurus, ecto-parasites, Nagpur, Odonata, water mites, Wena Dam.
More than 55 mites of the genus Arrenurus mites have been described as ectoparasites of Odonata (Corbet 1999). During the final emergence, the mite larvae crawl from the exuvia to the newly emerged adult and become parasitic (Abro 1982; Andre \& Cordero 1998; Zawal 2006) and remain attached to the host throughout the pre-reproductive period of the host but drop off in water when the odonate comes to copulate and oviposit in a water body. But after the study of Andrew et al. (2012a, b) very little is known about the natural history of these parasitic mites. The present paper incorporates the results of an investigation carried out during the year 2011-12 to survey odonate diversity and mite parasitic load on odonates at Wena Dam of central India.

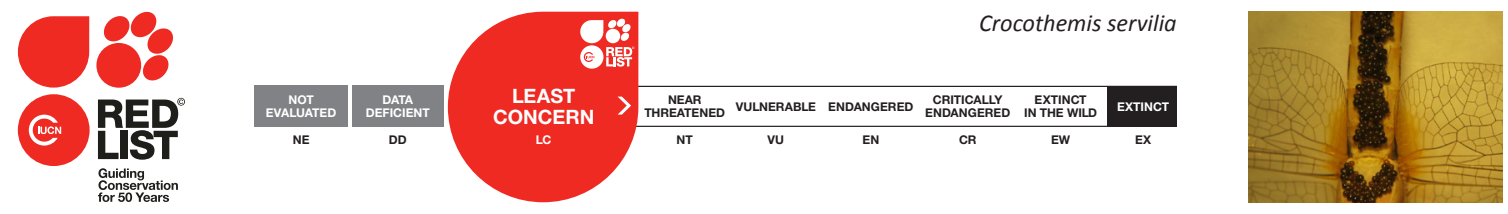

DOI: http://dx.doi.org/10.11609/JoTT.03913.6821-5 | ZooBank: urn:Isid:zoobank.org:pub:AE87313D-6E26-449A-A9D4-D7BD8DB27942

Editor: B.A. Daniel, Zoo Outreach Organization, Coimbatore, India

Date of publication: 26 January 2015 (online \& print)

Manuscript details: Ms \# 03913 | Received 11 January 2014 | Final received 07 January 2015 | Finally accepted 09 January 2015

Citation: Andrew, R.J., P.R. Verma \& N.R. Thaokar (2015). A parasitic association of Odonata (Insecta) with Arrenurus Dugés, 1834 (Arachnida: Hydrachnida: Arrenuridae) water mites. Journal of Threatened Taxa 7(1): 6821-6825; http://dx.doi.org/10.11609/JoTT.03913.6821-5

Copyright: @ Andrew et al. 2015. Creative Commons Attribution 4.0 International License. JoTT allows unrestricted use of this article in any medium, reproduction and distribution by providing adequate credit to the authors and the source of publication.

Funding: Self funded.

Competing Interest: The authors declare no competing interests.

Acknowledgements: We thank the Principal Dr. Mrs. D. R. Christian and Management of Hislop College, Nagpur for providing us laboratory facilities. 


\section{MethodS}

Wena (Vena/ Wana) dam is a mid-sized reservoir built on Wena River and is situated on National Highway No. 6 between the cities of Nagpur and Amravati in the state of Maharashtra (central India). It is located at $21^{\circ} 9^{\prime} 6^{\prime \prime} \mathrm{N} \& 78^{\circ} 52^{\prime} 0^{\prime \prime} \mathrm{E}$ near Wadgaon Village in Umred Taluka of Nagpur District. It lies $18 \mathrm{~km}$ west to Nagpur City and provides water to the Ordnance factory and Kalmeshwar MIDC Area. The area lies in the southern fringe of Satpuda mountain range $\left(21^{\circ} 10^{\prime} \mathrm{N} \& 79^{\circ} 12^{\prime} \mathrm{E}\right)$ and is an undulating plateau with altitudes ranging between 274-305 $\mathrm{m}$. The diurnal temperature varies from a minimum of $10^{\circ} \mathrm{C}$ in Dec-Jan (winter) to a maximum of $46^{\circ} \mathrm{C}$ in May-June (summer). The rainfall varies from 100-200 cm which precipitates mostly during the monsoon from June to September.

The odonate specimens were collected, photographed and were identified using standard manuals (Fraser 1933-36; Subramanian 2005; Andrew et al. 2008) to confirm their identity and later released. The details of the odonates parasitized with mites were noted and/or photographed. Some parasitized odonates were preserved in alcohol and Bouin's fluid for further investigation.

\section{RESULTS}

Arrenurus species are the only aquatic mites which form an ecto-parasitic association with adult odonates, the other two species which form a parasitic relationship are terrestrial mites, Hydraphantes and Limnochares spp. (Corbet 1999). During the study, 376 odonate species were examined for the presence of water mites. We found 35 odonates parasitized with Arrenurus mites (Images 1-7). These odonates belonged to the following species: Acisoma panorpoides Rambur, 1842 (5), Brachydiplax sobrina (Rambur, 1842) (2), Ceriagrion coromandelianum (Fabricius, 1798) (2), Crocothemis servilia (Drury, 1770) (14), Diplacodes trivialis (Rambur, 1842) (4), Neurothemis t. tullia (Drury, 1773) (4), and Trithemis pallidinervis (Kirby, 1889) (4). The specieswise prevalence of infestation is given in Table 1 . The mites were found attached to the undersurface of the thorax and abdomen. In Odonata, the ventralposterior region of the synthorax is composed of the fused metathoracic epimera sclerites and the central ' $V$ ' shaped pseudosternum cuticular plate forming an inverted Y shaped suture (Tillyard 1917; Chao 1953). The mites initially attach themselves to the suture and later invade the pseudosternum and then the ventral region of the epimera thereby invading the complete
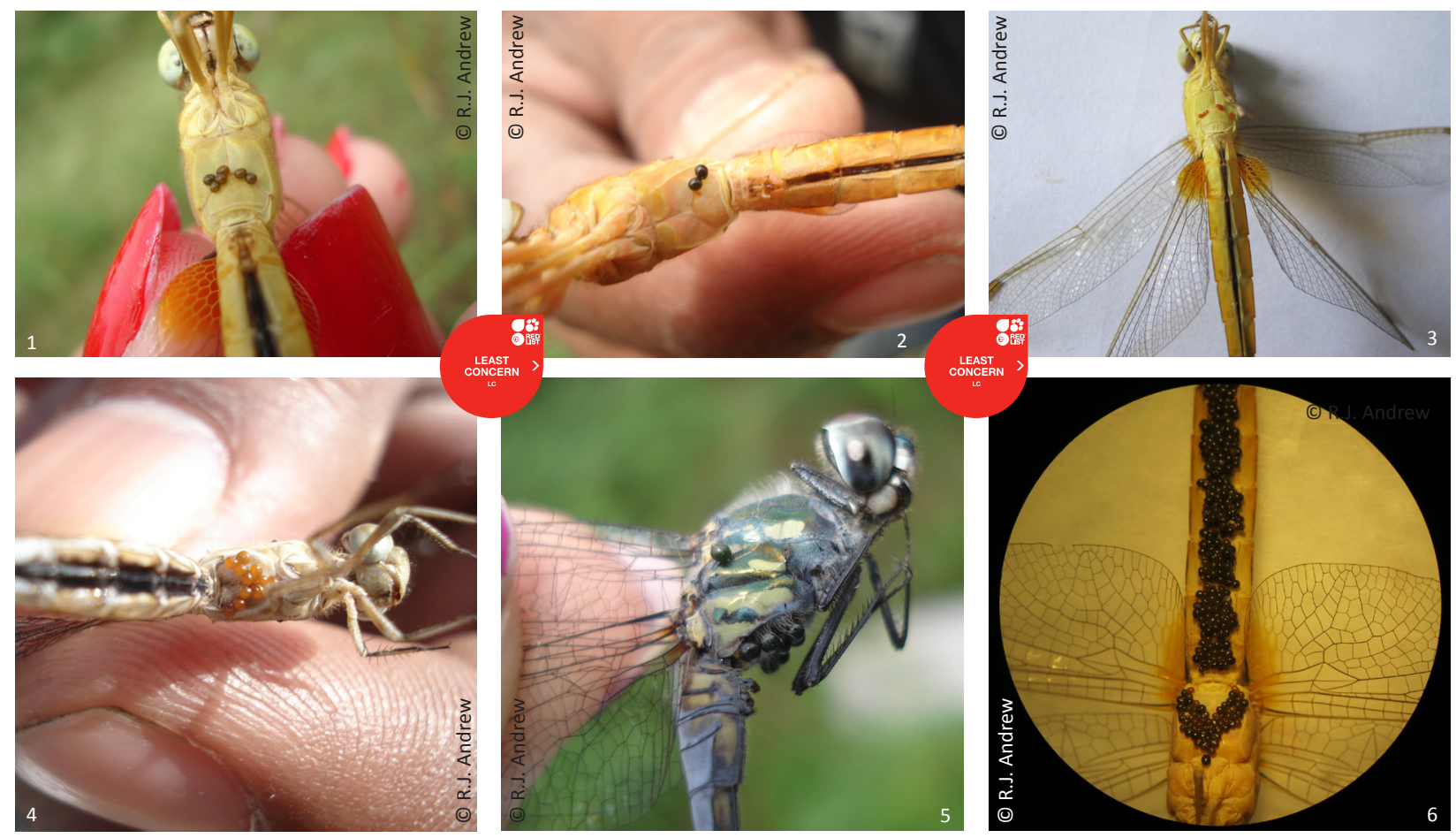

Images 1-6. Arrenurus mite infestation on the thorax and abdomen of odonates of Wena Dam.

Crocothemis servilia (1M, 2M, 3F, 6F); Acisoma panorpoides (4F); Brachydiplax sobrina (5M). (M - male; F - female). 
Table 1. List of Arrenurus aquatic mite infestation on Odonates at Wena Dam

\begin{tabular}{|c|c|c|c|c|c|c|}
\hline & \multirow{2}{*}{ Species } & \multicolumn{2}{|l|}{ Thorax } & \multicolumn{3}{|c|}{ Abdomen } \\
\hline & & Number & Colour & Number & Colour & Segment \\
\hline 1 & Crocothemis servilia (M) & 06 & Dark green & - & - & - \\
\hline 2 & C. servilia (M) & 02 & Black & - & - & - \\
\hline 3 & C. servilia (M) & 10 & Orange & - & - & - \\
\hline 4 & C. servilia (M) & 07 & Orange & - & - & - \\
\hline 5 & C. servilia (M) & 44 & Orange green & 1 & Orange green & 1 \\
\hline 6 & C. servilia (M) & 04 & Orange & - & - & - \\
\hline 7 & C. servilia (M) & 03 & Black & - & - & - \\
\hline 8 & C. servilia (M) & 08 & Orange & - & - & - \\
\hline 9 & C. servilia (M) & 25 & Orange & - & - & - \\
\hline 10 & C. servilia (F) & 05 & Dark green & 1 & - & III \\
\hline 11 & C. servilia (F) & 01 & Orange & - & - & - \\
\hline 12 & C. servilia (F) & 73 & Black & 220 & Black & All \\
\hline 13 & C. servilia (F) & 08 & Orange & - & - & - \\
\hline 14 & C. servilia (F) & 32 & Black & 06 & Black & I, II \\
\hline 15 & Diplacodes trivialis (M) & 02 & Dark green & - & - & - \\
\hline 16 & D. trivialis (F) & 04 & Dark green & - & - & - \\
\hline 17 & D. trivialis (F) & 10 & Dark green & - & - & - \\
\hline 18 & D. trivialis (F) & 08 & Dark green & - & - & - \\
\hline 19 & Neurothemis tullia tullia (M) & 01 & Orange & - & - & - \\
\hline 20 & N.t. tullia (M) & 02 & Dark green & - & - & - \\
\hline 21 & N.t.tullia(M) & 06 & Orange & - & - & - \\
\hline 22 & N.t.tullia (F) & 04 & Orange & - & - & - \\
\hline 23 & Acisoma panorpoides (M) & 02 & Orange & - & - & - \\
\hline 24 & A. panorpoides (F) & 18 & Orange & 34 & Orange & I, IV \\
\hline 25 & A. panorpoides $(\mathrm{F})$ & 01 & Orange & - & - & - \\
\hline 26 & A. panorpoides (F) & 12 & Orange & - & - & - \\
\hline 27 & A. panorpoides (F) & 08 & Orange & - & - & - \\
\hline 28 & Brachydiplax sobrina (M) & 08 & Dark green & - & - & - \\
\hline 29 & B. sobrina (M) & 05 & Dark green & - & - & - \\
\hline 30 & Ceriagrion coromandelianum (F) & 01 & Dark green & - & - & - \\
\hline 31 & C. coromandelianum (F) & 04 & Dark green & - & - & - \\
\hline 32 & Trithemis pallidinervis (M) & 15 & Orange & - & - & - \\
\hline 33 & T. pallidinervis (F) & 25 & Orange & 98 & Orange & All \\
\hline 34 & T. pallidinervis (F) & 18 & Orange & 116 & Orange & All \\
\hline 35 & T. pallidinervis $(\mathrm{F})$ & 09 & Orange & - & - & - \\
\hline
\end{tabular}

postero-ventral surface of the synthorax during severe infestation. Some may even move laterally along the metathoracic pleural sutures. In the abdomen, the mites initially attach themselves to the soft pleural folds between the abdominal sterno-tergum or between the inter tergal membranes. The site of attachment is often chosen where there is less sclerotisation of the host cuticle (Baker et al. 2007). Although, there are reports of Arrenurus attached to the basal region of the wings (Abro 1982), such a condition was never found during the present study.

In all the cases the thorax was found infested, while only in seven individuals the abdomen as well as the thorax was found to be infested with mites. A maximum 
Table 2. Prevalence of Arrenurus aquatic mite infestation on odonates at Wena Dam.

\begin{tabular}{|c|l|c|c|}
\hline & Species & $\begin{array}{c}\text { Total number } \\
\text { of infected } \\
\text { host }\end{array}$ & $\begin{array}{c}\text { Prevalence of } \\
\text { infestation }\end{array}$ \\
\hline 1 & Acisoma panorpoides & 5 & $14.28 \%$ \\
\hline 2 & Brachydiplax sobrina & 2 & $5.71 \%$ \\
\hline 3 & Ceriagrion coromandelianum & 2 & $5.71 \%$ \\
\hline 4 & Crocothemis servilia & 14 & $40 \%$ \\
\hline 5 & Diplacodes trivialis & 4 & $11.42 \%$ \\
\hline 6 & Neurothemis tullia tullia & 4 & $11.42 \%$ \\
\hline 7 & Trithemis pallidinervis & 4 & $11.42 \%$ \\
\hline
\end{tabular}

number of mites on an individual dragonfly was in $C$. servilia (293) followed by T. pallidinervis (134) while the highest parasitic load per individual host species was found in T. pallidinervis (70.25\%) followed by $C$. servilia (32.6\%). In D. trivialis, N.t. tullia, A. panorpoides, B. sobrina and $C$. coromandelianum the parasitic load per individual host species was found to be 6, 3.2, 15, 6.5 and 2.5, respectively. Among the 35 infected individuals 17 were males and 18 were females. The average parasitic load of female was $39.77 /$ individual and for the male it was 8.9/individual (Tables 2, 3).

\section{DISCUSSION}

Water mites have three active stages: larva, deutonymph and adult. Deutonymph and adult mites are predators and the larva of most species is parasitic. Several orders of aquatic insects are hosts for water mites: Colembolla, Coleoptera, Diptera, Heteroptera, Odonata, Plecoptera and Trichoptera (Martin 2008). In Arrenurus Dugés, the initial period of attachment by the larva to its larval host (phoretic period) is followed by a parasitic stage on adult odonates. Arrenurus is one of the most speciose water mite genera, occurring in most zoogeographic regions (Zawal 2008). The overall prevalence of Arrenurus mite infestation on odonates was $9.3 \%$ at Wena Dam. While it is $6.86 \%$ at Telenkhedi pond of Nagpur City (Andrew et al. 2012a) suggesting that the mite population of Wena Dam is higher than that of Telenkhedi Pond. The present paper reports the first record of Arrenurus infestation in a zygopteran odonate i.e. C. coromandelianum. In the present study it has been observed that the mite prefer the thoracic region as the site of attachment. A similar situation was reported by (Botman et al. 2002; Zawal 2006; Zawal \& Dyatlova 2006) although in the Zygoptera Lestes sponsa, the mites exclusively prefer the abdominal region (Zawal
Table 3. Number of Arrenurus aquatic mites on male and female odonates of Wena Dam

\begin{tabular}{|l|c|c|c|c|}
\hline \multirow{2}{*}{ Host species } & \multirow{2}{*}{$\begin{array}{c}\text { Infected } \\
\text { host }\end{array}$} & \multicolumn{3}{|c|}{ Number of mites } \\
\cline { 3 - 5 } & Male & Female & Total \\
\hline Acisoma panorpoides & $1 \mathrm{M}, 4 \mathrm{~F}$ & 02 & 73 & 75 \\
\hline Brachydiplax sobrina & $2 \mathrm{M}$ & 13 & - & 13 \\
\hline Ceriagrion coromandelianum & $2 \mathrm{~F}$ & - & 05 & 05 \\
\hline Crocothemis servilia & $9 \mathrm{M}, 5 \mathrm{~F}$ & 110 & 346 & 456 \\
\hline Diplacodes trivialis & $1 \mathrm{M}, 3 \mathrm{~F}$ & 02 & 22 & 24 \\
\hline Neurothemis tullia tullia & $3 \mathrm{M}, 1 \mathrm{~F}$ & 09 & 04 & 13 \\
\hline Trithemis pallidinervis & $1 \mathrm{M}, 3 \mathrm{~F}$ & 15 & 266 & 281 \\
\hline Total & $17 \mathrm{M}, 16 \mathrm{~F}$ & 151 & 716 & 867 \\
\hline
\end{tabular}

F- females; M - males

2004, 2006).

The mite infestation was not host or sex specific since the ratio was almost equal (17 males, 18 females), but the parasitic load per female $(39.77 \%)$ was much higher than the male $(8.9 \%)$ indicating that the mites preferred females to males although reproductive behaviour is supposed to favour the female as a preferential host as postulated by some workers (Forbes et al. 2004; Robb \& Forbes 2006; Andrew et al. 2012a). In the female, vitellogenesis during egg maturation results in the passage of nutritive rich material through the haemolymph during the pre-reproductive period (Tembhare 2012). Since the mites feed on haemolymph, we believe that it is more beneficial to the mite to choose a female as host. The mites engorge on this nutritive material and probably develop faster in comparison with those infecting the male. The mites were found in three colours, orange (18 individuals), dark green (11), and black (4). The mites progressively change colour almost in unison and therefore the colour pattern on an individual host is uniform as found in the present study. This contention was further strengthened by the observation that there was no colour differentiation between the thoracic and abdominal mites and all the mites of the individual simultaneously change colour during their growth and development. In one dragonfly C. servilia, all the 45 mites on the hosts thorax and abdomen were found in a transitional stage with a green centre and an orange fringe along the border. The only infected Zygoptera found in Wena reservoir were two females of $C$. coromandelianum.

\section{REFERENCES}

Åbro, A. (1982). The effect of parasitic water mite larvae (Arrenurus spp.) on Zygopteran imagoes (Odonata). Journal of Invertebrate 
Pathology 39: 373-381.

Andre, J. \& A. Cordero (1998). Effects of water mite on damselfly Ceriagrion tenellum. Ecological Entomology 23: 103-109.

Andrew, R.J., K.A. Subramanian \& A.D. Tiple (2008). A Handbook of Common Odonates of Central India. Published by the South Asian Council of Odonatology (SACO), India, for the 18th International Symposium of Odonatology, 54pp.

Andrew, R.J., N. Thaokar \& P. Verma (2012a). Ectoparasitism of anisopteran dragonflies (Insecta: Odonata) by water mite larvae of Arrenurus spp. (Arachnida: Hydrachnida: Arrenuridae) in Centra India. Acarina 20(2): 194-198.

Andrew, R., P. Verma \& N. Thaokar (2012b). Seasonal variation and mite infestation in the anisopteran dragonflies of Gorewada lake of Nagpur City, India. Vidyabharati International Interdisciplinary Research Journal 1(1): 1-10.

Baker, R.A., P.J. Mills \& A. Zawal (2007). Mites on damselflies, with particular reference to Arrenurus species selection sites and host preferences. Odonatologica, 36: 339-347.

Botman, G., L. Coenen \& C.A. Lanciani (2002). Parasitism of Ischnura posita (Odonata: Coenagrionidae) in Florida by two species of water mites. Florida Entomologist 85: 279-280.

Chao, H.F. (1953). The external morphology of the dragonfly, Onchogomphus ardens Needham. Smithson Miscellaneous Collection 122(6): 1-56.

Corbet, P.S. (1999). Dragonflies: Behavior and Ecology of Odonata. Harley Books (B.H. Harley and A. Harley Ltd.), Great Horkesley, England, 829pp.

Forbes, M.R., K.E. Muma \& B.P. Smith (2004). Recapture male and female dragonflies in relation to parasitism by mites, time of season, wing-length and wing cell asymmetry. Experimental and Applied Acarology 34: 79-93.
Fraser, F.C. (1933, 1934, 1936). The fauna of British India including Ceylon and Burma: Odonata, Vols. I-3. Taylor and Francis, London, $461 \mathrm{pp}$

Martin, P. (2008). Water mites (Hydrachnidia, Acari) and insects: a survey of a seldom consideredrelationship. Entomologie Heute 20: 45-75.

Robb, T. \& M.R. Forbes (2006). Sex basis in parasitism of newly emerged damselflies. Ecoscience 13: 1-4.

Subramanian, K.A. (2005). Dragonflies and Damselflies of peninsular India; A Field Guide. E. Book of Project lifescape. Center for Ecological Sciences. I.I.S. and I.A.S. Bangalore, India.

Tembhare, D.B. (2012). Modern Entomology - (2 ${ }^{\text {nd }}$ Edition). Himalaya Publishing House, Mumbai, 623pp.

Tillyard, R.J. (1917). The Biology of Dragonflies. Cambridge University Press, England, 398pp.

Zawal, A. (2004). Parasitizing of dragonflies by water mite larvae of the genus Arrenurusin the neighborhood of the Barlinek (NW Poland). Zoolgica Poloniae 49: 37-45.

Zawal, A. (2006).Phoresy and parasitism: water mite larvae of the genus Arrenurus (Acari: Hydrachnidia) on Odonata from Lake Binowskie (NW Poland). Biological Letters 43(2): 257-276.

Zawal, A. \& E.S. Dyatlova (2006). Preliminary data for parasitizing on Ischnura elegans (Vander Linden, 1820) (Odonata: Coenagrionidae) by Arrenurus (Acari: Hydrachnidia) larvae from Odessa province (Southwestern Ukraine). Proceedings of the Symposium, II International Symposium of Ecologists of Montenegro, 17-20.

Zawal, A. (2008). Morphological characteristics of water mite larvae of the genus Arrenurus Dugés 1834, with notes on the phylogeny of the genus and an identification key. Zootaxa 1765: 1-75.

Wing 